\title{
Seismogenesis in Central Apennines, Italy: an integrated analysis of minor earthquake sequences and structural data in the Amatrice-Campotosto area
}

\author{
Paolo Boncio $\left({ }^{1}\right)$, Giuseppina Lavecchia $\left({ }^{1}\right)$, Giuliano Milana $\left({ }^{2}\right)$ and Barbara Rozzi $\left({ }^{1}\right)$ \\ ${ }^{1}{ }^{1}$ Laboratorio di Geodinamica e Sismogenesi, Dipartimento di Scienze della Terra, \\ Università degli Studi di Chieti «G. D’Annunzio», Chieti, Italy \\ ${ }^{2}$ ) Istituto Nazionale di Geofisica e Vulcanologia, Roma, Italy
}

\begin{abstract}
We present a seismotectonic study of the Amatrice-Campotosto area (Central Italy) based on an integrated analysis of minor earthquake sequences, geological data and crustal rheology. The area has been affected by three small-magnitude seismic sequences: August $1992(M=3.9)$, June $1994(M=3.7)$ and October 1996 $(M=4.0)$. The hypocentral locations and fault plane solutions of the 1996 sequence are based on original data; the seismological features of the 1992 and 1994 sequences are summarised from literature. The active WSWdipping Mt. Gorzano normal fault is interpreted as the common seismogenic structure for the three analysed sequences. The mean state of stress obtained by inversion of focal mechanisms (WSW-ENE-trending deviatoric tension) is comparable to that responsible for finite Quaternary displacement, showing that the stress field has not changed since the onset of extensional tectonics. Available morphotectonic data integrated with original structural data show that the Mt. Gorzano Fault extends for $\sim 28 \mathrm{~km}$ along strike. The along-strike displacement profile is typical of an isolated fault, without significant internal segmentation. The strong evidence of late Quaternary activity in the southern part of the fault (with lower displacement gradient) is explained in this work in terms of displacement profile readjustment within a fault unable to grow further laterally. The depth distribution of seismicity and the crustal rheology yield a thickness of $\sim 15 \mathrm{~km}$ for the brittle layer. An area of $\sim 530 \mathrm{~km}^{2}$ is estimated for the entire Mt. Gorzano Fault surface. In historical times, the northern portion of the fault was probably activated during the 1639 Amatrice earthquake $(I=\mathrm{X}, M \sim 6.3)$, but this is not the largest event we expect on the fault. We propose that a large earthquake might activate the entire $28 \mathrm{~km}$ long Mt. Gorzano Fault, with an expected $M_{\max }$ up to 6.7 .
\end{abstract}

Key words Apennines - normal faulting - seismicity - seismotectonics - active stress - seismic hazard

Mailing address: Dr. Paolo Boncio, Laboratorio di Geodinamica e Sismogenesi, Dipartimento Scienze della Terra, Università degli Studi di Chieti «G. D'Annunzio», Via dei Vestini 30, 66013 Chieti Scalo $(\mathrm{CH})$, Italy; e-mail: pboncio@unich.it

\section{Introduction}

Defining the 3D geometry and the possible seismogenic behaviour of active faults is an open problem with implications on seismic hazard, especially when geological data are the main ingredients for seismic hazard assessment. The problem covers different aspects of earthquake faulting, including long- and shortterm geological recording of faulting, rock mechanics and seismogenesis. Interdisciplinary analyses, aimed to integrate seismological data 
with geological studies (field mapping, morphotectonics and paleoseismology, structural analysis, active and paleo-stress inversion, thermo-mechanical analysis), may help to constrain the geometry and kinematics and, to some extent, the expected seismogenic behaviour of active faults. In this context, the information given also by minor seismic sequences $(M \leq 4.0)$ recorded by local networks may be helpful. Local network recordings and detailed seismological analyses may allow accurate hypocentral locations and focal mechanism determinations, which can be compared with independent geological observations.

In this work we analyse an area of active faulting which is not clearly understood from a seismotectonic point of view: the AmatriceCampotosto area of Central Apennines, Italy (fig. 1). The area was affected by a strong historical earthquake in 1639 (Amatrice earth-

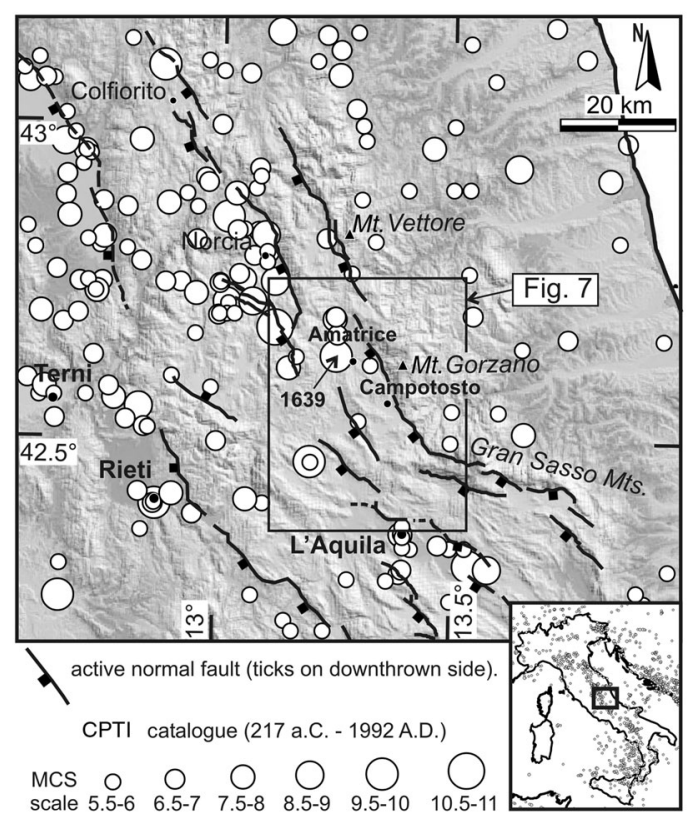

Fig. 1. Shaded relief of Central Apennines with major active normal faults, historical earthquakes from CPTI catalogue (Gruppo di Lavoro CPTI, 1999) and location of the Amatrice-Campotosto area (box). quake, $I=\mathrm{X})$, by a number of small-to-moderate earthquakes since 1000 A.D. ( $I<$ VIII, fig. 1$)$ and also by three minor earthquake sequences during the last decade (August 1992, $M=3.9$; June 1994, $M=3.7$ and October 1996, $M=4.0$ ). Previous studies have dealt in detail with seismological aspects of the instrumental seismicity (e.g., De Luca et al., 2000) or historical earthquakes (see Gruppo di Lavoro CPTI, 1999 and references therein). A number of geological, morphological and paleoseismological studies, which recognised evidence of active normal faulting, are also available in the geological literature (Demangeot, 1965; Bachetti et al., 1990; Marsili and Tozzi, 1991; Blumetti et al., 1993; Cacciuni et al., 1995; Bagnaia et al., 1996; Galadini and Galli, 2000; Galadini and Messina, 2001). Nevertheless, there are no works that attempt to integrate surface geological data with detailed seismological data, in order to investigate the relationships between geologically recognisable structures and their likely seismic behaviour. The lack of integrated studies is probably the cause of the lack of consensus on the geometry, seismic behaviour and seismogenic potential of one of the most important structures of the area: the $28 \mathrm{~km}$ long Mt. Gorzano normal fault. In particular, in the Database of Italy's Seismogenic Sources (Valensise and Pantosti, 2001), the Mt. Gorzano Fault is split into two distinct seismogenic segments, each $\sim 14 \mathrm{~km}$ long and with an expected maximum magnitude $\left(M_{w}\right)$ of 6.1. The northern segment roughly corresponds to the rupture of the 1639 Amatrice earthquake; the southern one is not associated with historical earthquakes. In other active fault compilations (Barchi et al., 2000; Galadini and Galli, 2000), the northern portion of the Mt. Gorzano Fault is considered inactive since late Quaternary times and its association with the 1639 earthquake is considered questionable; the central-southern portion of the Mt. Gorzano Fault, that shows clear evidence of late Quaternary activity (length $\sim 20 \mathrm{~km}$ ), is assumed to be seismogenic and the computed maximum expected magnitude is of the order of 6.6.

Here, we analyse the seismic records of the October 1996 Campotosto sequence $\left(M_{\max }=\right.$ $=4.0)$, registered by the local networks of the Servizio Sismico Nazionale (SSN). We inte- 
grate our results with data form the literature on the $1992\left(M_{\max }=3.9\right)$ and $1994\left(M_{\max }=3.7\right)$ earthquake sequences, which occurred north of the town of L'Aquila (De Luca et al., 2000). The focal mechanisms of the three sequences are inverted and the related deviatoric stress field calculated. The thickness of the upper crust brittle layer is deduced by integrating seismological data with crustal strength analysis through rheologic profiling. The possible seismotectonic meaning of the observed seismicity is analysed in the light of the Quaternary geological features and seismic history of the Amatrice-Campotosto area, with particular attention to the Mt. Gorzano normal fault. Geologic, geomorphologic and paleosismologic data from literature are integrated with original structural data in order to constrain the attitude, longitudinal continuity, map pattern, structural complexities and kinematics of the fault. The association of the Mt. Gorzano Fault with large earthquakes of the past is discussed and considerations on the maximum seismogenic potential are proposed.

\section{Seismotectonic context}

The epicentral areas of the 1992, 1994 and 1996 seismic sequences are located between two NNW-SSE-trending regional systems of active normal faults (fig. 1). The western system develops from Colfiorito to Norcia to L'Aquila; the eastern system develops from Mt. Vettore to Amatrice-Campotosto to Gran Sasso Mts. (Calamita and Pizzi, 1992; Cello et al., 1997; Boncio and Lavecchia, 2000; Galadini and Galli, 2000; Pizzi and Scisciani, 2000; Lavecchia et al., 2002 and references therein). Both systems offset Mio-Pliocene fold-andthrust structures, often generating intramontane depressions. Displacements on Late Pleistocene-Holocene deposits and paleoseismic activity are widely documented (see Barchi et al., 2000; Galadini and Galli, 2000; Valensise and Pantosti, 2001 and references therein).

The western system is highly seismogenic (Galadini et al., 1999; Lavecchia et al., 2002). The faults at the northern part of the system were activated by the 1979 Norcia $\left(M_{w}=5.8\right)$ and 1997 Colfiorito $\left(\max M_{w}=6.0\right)$ normal faulting earthquakes. The Norcia-L'Aquila Fault alignment was activated during January-February 1703 by a SE-propagating multiple-rupture seismic sequence consisting of several shocks with three main events (January 14, $I=\mathrm{XI}, M=6.7$; January $16, I=$ VIII, $M=6.0$; and February 02, $I=\mathrm{X}, M=6.6$ : Stucchi, 1985; Blumetti, 1995; Boschi et al., 1997). Other strong historical earthquakes associated with the activity of the western system are the $1328(I=\mathrm{X}, M=6.4), 1461(I=\mathrm{X}$, $M=6.5), 1599$ ( $I=$ VIII-IX, $M=5.8), 1730$ ( $I=$ $=$ VIII-IX, $M=5.8), 1762(I=\mathrm{IX}, M=5.9)$, and 1859 ( $I=$ VIII-IX, $M=5.6$ ) events ( $I=$ epicentral intensity and $M=$ average magnitude are from the CPTI catalogue; Gruppo di Lavoro CPTI, 1999).

The seismogenic behaviour of the eastern fault system is less clear. The Mt. Vettore and Gran Sasso faults seem to have been silent since historical times. The Amatrice-Campotosto area, in the hanging wall of the central fault of the system (Mt. Gorzano Fault), was struck by only one large historical earthquake in October $1639(I=\mathrm{X}, M=6.3)$ and by a number of smallto-moderate events: July 1627 ( $I=$ VII-VIII, $M=$ $=5.1$ ), November 1883 ( $I=\mathrm{VII}, M=4.8)$, February $1906(I=\mathrm{VI}, M=4.3)$, December 1910 ( $I=$ $=\mathrm{VII}, M=4.8)$, March 1950 ( $I=\mathrm{VII}, M=4.8)$, and July 1963 ( $I=\mathrm{VI}, M=4.3$ ) (Gruppo di Lavoro CPTI, 1999). Since the availability of instrumental records, the area has been affected only by minor earthquakes $(M \leq 4.0)$ and spread microseismicity (1981-1996 catalogue, INGGNDT, 2001).

\section{The minor seismic sequences}

\subsection{Data analysis of the 1996 Campotosto seismic sequence}

From 18th October, 1996 until 21st October, 1996 the seismic networks of the Servizio Sismico Nazionale (SSN) recorded an earthquake sequence, preliminarily localised near the Campotosto Lake. The networks were located in the Abruzzo, Eastern Lazio, Umbria and Marche regions of Central Italy (fig. 2a), and were managed in cooperation with the University of L'Aquila (Abruzzo), the «A. Bina» Observatory 

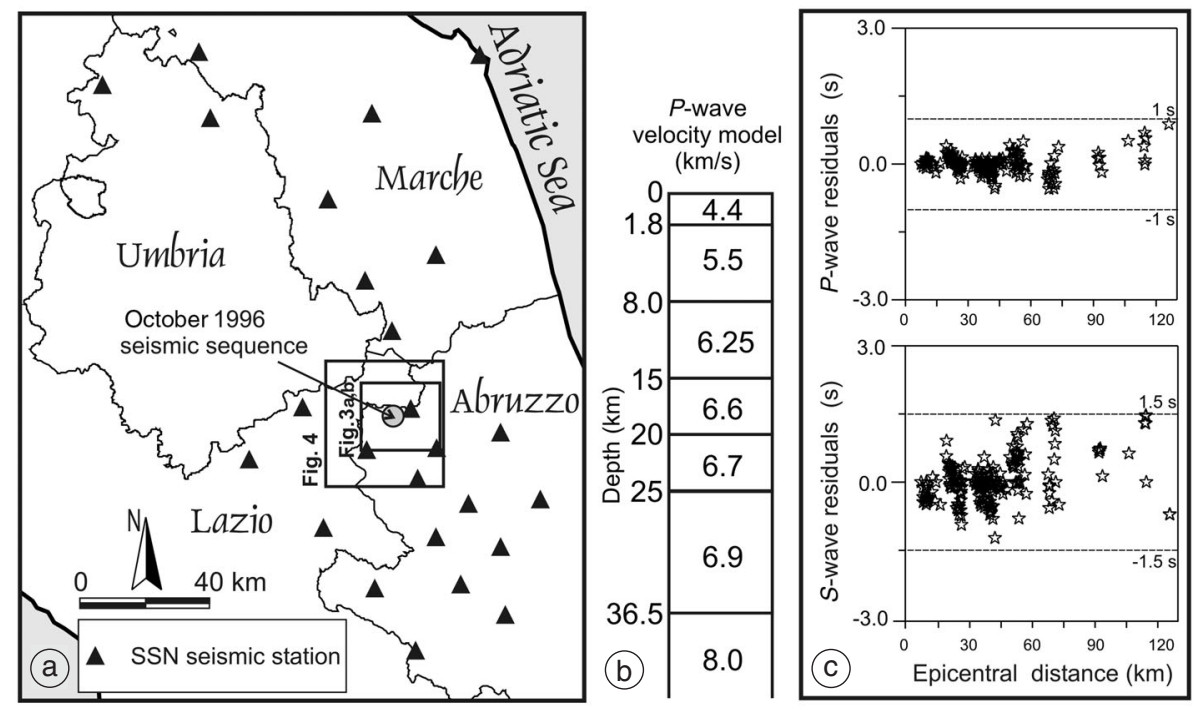

Fig. 2a-c. a) Seismic stations of the Servizio Sismico Nazionale network in the Abruzzo, Marche, Lazio and Umbria regions that provided the recordings of the October 1996 sequence; all the stations were three-components (Lennartz Mars88 digital) and equipped with Mark L-4C $1 \mathrm{~Hz}$ seismometers; b) 1D velocity model used for hypocentral location; c) distribution of $P$ - and $S$-wave residuals versus epicentral distance for the 1996 seismic sequence.

Table I. Hypocentral parameters of the October 1996 seismic sequence computed with the Hypoellipse software (Lahr, 1999), using the 1D velocity model of fig. 2 b. A, D and L are the azimuth $\left(^{\circ}\right)$, dip $\left(^{\circ}\right)$ and length $(\mathrm{km})$ of the 3 error ellipsoid semi-axes, respectively.

\begin{tabular}{|c|c|c|c|c|c|c|c|c|c|c|c|c|c|c|}
\hline \multirow[t]{2}{*}{ No. } & \multirow[t]{2}{*}{ Date } & \multirow[t]{2}{*}{ Lat. } & \multirow[t]{2}{*}{ Long. } & \multirow{2}{*}{$\begin{array}{l}\text { Depth } \\
(\mathrm{km})\end{array}$} & \multirow[t]{2}{*}{$M_{l}$} & \multirow{2}{*}{$\begin{array}{c}\text { RMS } \\
\text { (s) }\end{array}$} & \multirow{2}{*}{$\begin{array}{c}\text { GAP } \\
\left(^{\circ}\right)\end{array}$} & \multicolumn{7}{|c|}{ Error ellipsoid } \\
\hline & & & & & & & & A1 & D1 & L1 & $\mathrm{A} 2$ & D2 & L2 & L3 \\
\hline 1 & $18.10 .199623: 03$ & 42.540 & 13.290 & 8.3 & 3.0 & 0.10 & 176 & 279 & 0 & 0.5 & 189 & 5 & 1.1 & 5.1 \\
\hline 2 & $20.10 .199600: 57$ & 42.533 & 13.289 & 10.6 & 2.5 & 0.16 & 72 & 35 & 0 & 0.6 & 305 & 1 & 0.5 & 3.7 \\
\hline 3 & 20.10.1996 01:32 & 42.544 & 13.288 & 10.0 & 1.8 & 0.15 & 119 & 235 & 1 & 0.8 & 325 & 3 & 0.5 & 2.3 \\
\hline 4 & 20.10.1996 01:56 & 42.544 & 13.285 & 10.6 & 2.8 & 0.16 & 78 & 326 & 4 & 0.5 & 236 & 5 & 0.7 & 2.4 \\
\hline 5 & $20.10 .199602: 33$ & 42.531 & 13.285 & 8.7 & 1.9 & 0.09 & 168 & 271 & 10 & 0.3 & 178 & 16 & 0.6 & 1.6 \\
\hline 6 & 20.10 .1996 16:52 & 42.549 & 13.282 & 10.1 & 2.9 & 0.15 & 81 & 319 & 2 & 0.4 & 229 & 2 & 0.5 & 2.0 \\
\hline 7 & 20.10 .1996 19:06 & 42.543 & 13.286 & 11.9 & 4.0 & 0.14 & 78 & 157 & 2 & 0.4 & 247 & 9 & 0.5 & 1.1 \\
\hline 8 & 20.10 .1996 19:43 & 42.542 & & 11.1 & 2.3 & & 77 & 209 & 1 & 0.5 & 299 & 3 & 0.4 & 1.9 \\
\hline 9 & $20.10 .199621: 41$ & 42.554 & 13.310 & 9.8 & 1.5 & 0.12 & 299 & 210 & 16 & 1.1 & 310 & 31 & 3.3 & 2.1 \\
\hline 10 & $20.10 .199622: 07$ & 42.557 & 13.324 & 10.0 & 1.7 & 0.03 & 319 & 332 & 0 & 2.9 & 62 & 10 & 2.7 & 1.1 \\
\hline 11 & $20.10 .199622: 33$ & 42.555 & 13.298 & 10.5 & 2.1 & 0.10 & 188 & 277 & 6 & 0.5 & 183 & 29 & 1.7 & 2.6 \\
\hline 12 & $21.10 .199605: 13$ & 42.559 & 13.295 & 12.1 & 2.7 & 0.14 & 190 & 123 & 28 & 1.3 & 232 & 32 & 2.8 & 5.7 \\
\hline 13 & 21.10.1996 09:32 & 42.509 & 13.278 & 11.4 & 1.9 & 0.07 & 151 & 267 & 6 & 0.7 & 174 & 27 & 1.5 & 3.7 \\
\hline 14 & 21.10.1996 11:41 & 42.548 & 13.277 & 11.9 & 2.6 & 0.14 & 79 & 268 & 3 & 0.5 & 358 & 4 & 0.4 & 1.7 \\
\hline 15 & $21.10 .199615: 11$ & 42.554 & 13.309 & 11.9 & 1.8 & 0.23 & 86 & 310 & 0 & 0.4 & 40 & 6 & 0.5 & 1.7 \\
\hline
\end{tabular}


(Umbria) and the Osservatorio Geofisico Sperimentale of Macerata (Marche). Almost all the stations of the net at 19:06 GMT of October 20 recorded the main shock, the magnitude of which was evaluated to be $4.0-4.1$ by the national seismic network of the Istituto Nazionale di Geofisica e Vulcanologia (INGV).

Here, the 1996 sequence is studied in detail through the analysis of 18 events selected among the SSN seismic records. The Scherbaum algorithm (Scherbaum, 1996) has been applied to all the vertical traces, in order to avoid anti-aliasing filter effects that can introduce fictitious impulse having polarity opposite to the real first arrival. The program used for the phase picking was PITSA (Scherbaum and Johnson, 1992). The sampling rate has been set to $125 \mathrm{~Hz}$ for the nets of Abruzzo, Umbria and Eastern Lazio, to 62.5 $\mathrm{Hz}$ for the Marche one. Subsequently, the sequence was localised using the Hypoellipse software (Lahr, 1999).

The choice of the velocity model was not simple because the studied area is located between regions of different geologic setting: the Umbria-Marche-Abruzzo Apennines, where
Meso-Cenozoic carbonate sequences prevail, and the deformed Marche-Abruzzo foredeep, where Late Miocene-Pliocene siliciclastic deposits extensively crop out (Bigi et al., 1992). The model that provided the best solutions in terms of travel-time residuals for each station was the one shown in fig. $2 b$, based on Deep Seismic Sounding (DSS) data across the Umbria-Marche Apennines (Ponziani et al., 1995). Actually, there are no systematic residual errors in $P$ and $S$ arrivals versus epicentral distance (fig. 2c). The used $V_{p} / V_{s}$ ratio is 1.85 , obtained by Wadati diagram. Among the 18 analysed earthquakes of the sequence, 15 events showed acceptable hypocentral locations; the related hypocentral parameters are listed in table I. The magnitudes have been calculated through the conversion of not clipped horizontal waveforms into equivalent Wood-Anderson seismograms. We have calculated a $M_{l}=4.0$ for the main shock, $M_{l}$ ranging from 1.8 to 3.0 for 6 events preceding the main shock and $M_{l}$ ranging from 1.5 to 2.7 for 8 aftershocks. The epicentral and hypocentral location of the sequence is shown in fig. 3a (absolute locations). To better define the
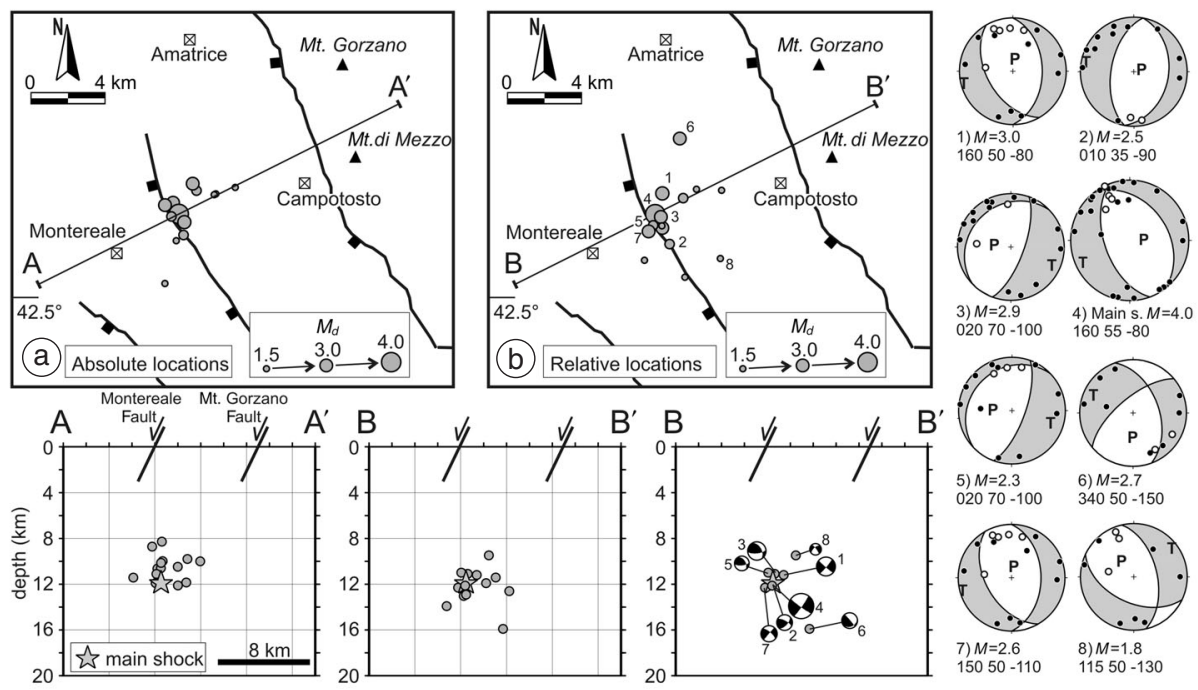

Fig. 3a,b. Absolute (a) and relative (b) locations of the October 1996 seismic sequence (hypocentral parameters in tables I and II); hypocentral sections, and focal mechanisms of the events having at least $10 P$-wave first motion observations. For each focal mechanism, the magnitude and the attitude of one nodal plane (strike, dip and rake according to the right-hand rule) are indicated. 
Table II. Hypocentral parameters from relative location of the October 1996 seismic sequence (main shock $=$ master event $)$.

\begin{tabular}{lcccc}
\hline \hline No. & Date & Lat. & Long. & $\begin{array}{c}\text { Depth } \\
(\mathrm{km})\end{array}$ \\
\hline 1 & $18.10 .199623: 03$ & 42.553 & 13.290 & 11.2 \\
2 & $20.10 .199600: 57$ & 42.529 & 13.295 & 12.1 \\
3 & $20.10 .199601: 32$ & 42.513 & 13.306 & 13.0 \\
4 & $20.10 .199601: 56$ & 42.536 & 13.290 & 12.9 \\
5 & $20.10 .199602: 33$ & 42.537 & 13.290 & 11.9 \\
6 & $20.10 .199616: 52$ & 42.542 & 13.289 & 11.1 \\
7 & $20.10 .199619: 06$ & 42.543 & 13.286 & 11.9 \\
8 & $20.10 .199619: 43$ & 42.538 & 13.284 & 11.0 \\
9 & $20.10 .199621: 41$ & 42.556 & 13.312 & 11.4 \\
10 & $20.10 .199622: 07$ & 42.556 & 13.329 & 12.6 \\
11 & $20.10 .199622: 33$ & 42.551 & 13.304 & 11.9 \\
12 & $21.10 .199605: 13$ & 42.581 & 13.301 & 15.9 \\
13 & $21.10 .199609: 32$ & 42.520 & 13.279 & 13.9 \\
14 & $21.10 .199611: 41$ & 42.535 & 13.282 & 12.3 \\
15 & $21.10 .199615: 11$ & 42.522 & 13.329 & 9.5 \\
\hline
\end{tabular}

hypocentral distribution, we attempted a relative location of the 1996 sequence by using the master event technique, considering the main shock as the master event. This choice is based on the assumption that the main shock is the best located event, having been recorded by almost all the stations of the net. All the other event locations are expressed as increments of time-space parameters compared to the main shock (Console and Di Giovambattista, 1987). After the relocation, a clustering at depths between 10 and $14 \mathrm{~km}$ is obtained, with the main shock located at a depth of $12 \pm 1 \mathrm{~km}$ (table II, fig. 3b). The cluster shows a westward dip along a WSWENE-trending cross-section (fig. 3a,b).

The focal mechanisms were computed using the FPFit program (Reasenberg and Oppenheimer, 1985). The events having at least ten clear $P$-wave first motion arrivals are shown in fig. 3a,b. A variability in the fault plane solutions, typical of small-magnitude sequences, is evident. Nevertheless, all the mechanisms have a prevailing extensional kinematics, with nearly-horizontal $T$-axes trending from WSW-ENE to WNW-ESE. The main shock has normal dip slip kinematics, with a slight left-lateral component along a plane dipping $55^{\circ}$ to the WSW and with slight right-lateral component along a plane dipping $36^{\circ}$ to the NE.

\subsection{A summary of the 1992 and 1994 seismic sequences}

During August 1992 and June 1994, the SSN recorded two seismic sequences in the Northern L'Aquila area, having main shocks of magnitude 3.9 and 3.7, respectively. The two seismic sequences were analysed by De Luca et al. (2000), who provided the epicentral locations, fault plane solutions and source parameters.

The 1992 sequence which started on August 25 with a main shock $(M=3.9)$ followed by several aftershocks that lasted for a few days (18 events with $0.5 \leq M \leq 2.3)$. The 1994 sequence started on June 2 with a foreshock $(M=2.9)$ followed in a few seconds by the main shock $(M=3.7)$ and several aftershocks that lasted for less than one day ( 13 events with $0.9 \leq M \leq 3.2$ ). The two sequences were located by using a 1D velocity model based on the Latina-Pescara (Central Italy) DSS profile (Nicolich, 1981) and by estimating a $V_{p} / V_{s}$ ratio equal to 1.80 . Both sequences are located between the epicentral area of the 1996 sequence and the town of L'Aquila (fig. 4). The 1992 sequence, located about $8 \mathrm{~km}$ to the north of L'Aquila, is elongated in the NNW-SSE direction. The 1994 sequence, located about $15 \mathrm{~km} \mathrm{NW}$ of L'Aquila, is elongated in the NE-SW direction.

In cross section (fig. 4), the 1992 hypocentres are located at depths between 7 and $13 \mathrm{~km}$; the main shock is at a depth of $12.3 \pm 1.4 \mathrm{~km}$. The 1994 hypocentres range in depth between 4 and $18 \mathrm{~km}$, with a cluster between 10 and 14 $\mathrm{km}$; the main shock is at a depth of $10.9 \pm 1 \mathrm{~km}$.

The fault plane solutions were calculated by using the $P$-wave first arrivals, integrated with $S$ wave polarization for the two main shocks (De Luca et al., 2000; fig. 4). The 1992 mechanisms have a prevailing extensional kinematics, with sub-horizontal $T$-axes trending from WSW-ENE to WNW-ESE; the main shock shows normal kinematics, with slight right-lateral component 

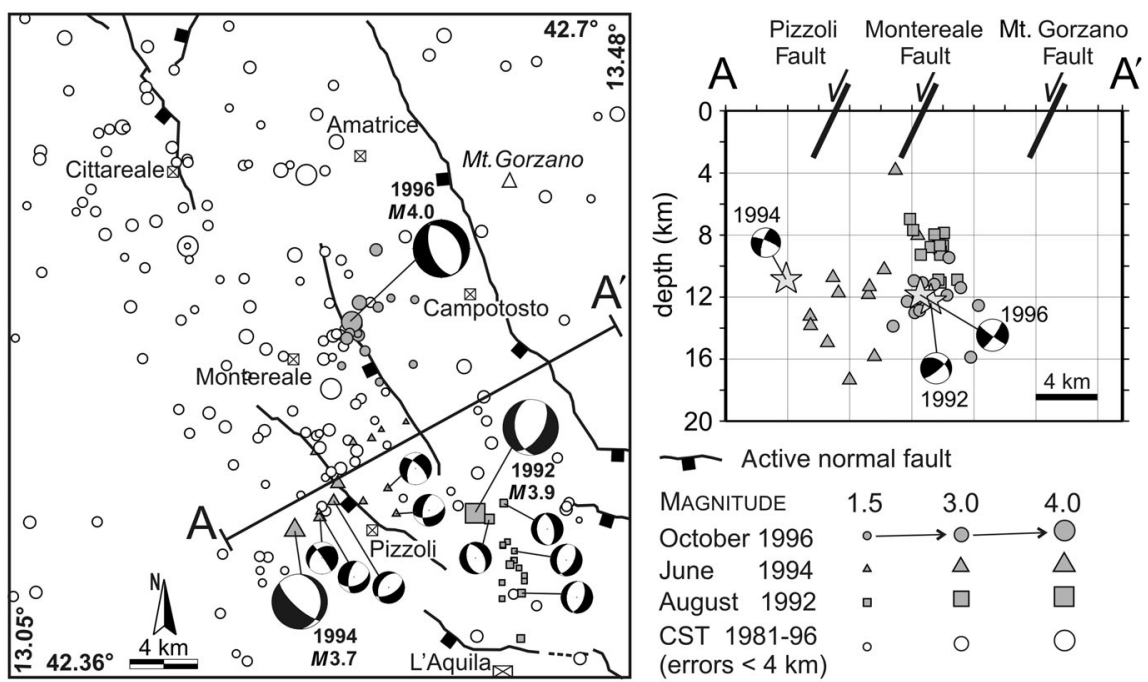

Fig. 4. Epicentral distribution of the best-located events of the 1996 sequence (present study) 1992 and 1994 sequences (from De Luca et al., 2000) and 1981-1996 seismicity from the CST catalogue (ING-GNDT, 2001; A and B quality, depth errors $<4 \mathrm{~km}$ ). Along the A-A' section, all the hypocentres of the 1992, 1994, and 1996 sequences and the focal mechanisms of the related main shocks are plotted.

along a plane dipping $42^{\circ}$ westward and with slight left-lateral component along a plane dipping $55^{\circ}$ to the ESE. The most constrained 1992 aftershocks show focal mechanisms very similar to the main shock solution. The 1994 mechanisms are more complex. The foreshock, the main shock and one of the aftershocks show normal-oblique kinematics with sub-horizontal $T$ axes trending from E-W to SW-NE; the main shock solution has a slight right-lateral component along a plane dipping $73^{\circ}$ to the SW and a slight left-lateral component along a plane dipping $25^{\circ}$ eastward. Three other aftershocks show normal-oblique kinematics with a sub-horizontal $T$-axes trending NW-SE.

\subsection{Depth distribution of the 1992, 1994, 1996} earthquakes and preliminary considerations on a possible seismogenic structure

In order to compare the depth distribution of the 1992, 1994 and 1996 sequences and to verify any possible genetic link with a common tectonic structure, we plotted all the hypocentral data on the same section oriented SW-NE (fig. 4). The section shows a WSW-dipping seismic band located between 7 and $17 \mathrm{~km}$. The seismicity lies along the ideal down-dip prolongation of the major normal fault outcropping in the area: the WSW-dipping Mt. Gorzano normal fault. The section view of the focal mechanisms of the three main shocks also appears to be compatible with a WSW-dipping preferred seismic plane, at least for the 1992 and 1996 sequences. At this point, the Mt. Gorzano Fault appears to be a good candidate as a common seismogenic structure. It is worth analysing in some detail its geometry, age and kinematics. Before this, we apply inversion techniques to the 1992, 1994 and 1996 focal mechanisms to identify the preferred seismic planes and to verify if they are compatible with a common stress tensor. We also compare the depth distribution of the minor seismicity in the Amatrice-Campotosto area with the crustal strength deduced by rheological analysis, in order to constrain the thickness of the seismogenic layer. 


\section{Active stress field and thickness of the seismogenic layer}

\subsection{Active stress field}

In order to calculate the active stress tensor, the 1992, 1994 and 1996 fault plane solutions were inverted using the methodology proposed by Mercier and Carey-Gailhardis (1989). This method consists of several steps. First, the graphic method of the right dihedra (Angelier and Mechler, 1977) is applied in order to test the kinematic compatibility of the fault population with a common stress tensor. The necessary (but not sufficient) condition for compatibility with a stress tensor common to all the faults is given by $100 \%$ of the data within the area defined by superposition of the dihedra delimited by nodal planes (fig. 5). Then, the Carey (1979) inversion method is applied to all the nodal planes to dis- tinguish the preferred seismic planes from the auxiliary ones. The preferred seismic planes, identified through a trial-and-error procedure, are those planes characterised by the best kinematic compatibility with the stress tensor common to the largest number of the analysed focal mechanisms (if possible, the total dataset). The kinematic compatibility is evaluated in terms of angular deviation $(t-s)$ between the calculated $(t)$ and observed $(s)$ slip vectors and on the theoretical shape factor $R\left(\left(\sigma_{2}-\sigma_{1}\right) /\left(\sigma_{3}-\sigma_{1}\right)\right)$ the stress tensor should have in order to justify the observed kinematics. Acceptable values for kinematic compatibility are $(t-s) \leq 20^{\circ}$ and $0 \leq R \leq 1$ (Mercier and Carey-Gailhardis, 1989). The final geometry of the stress ellipsoid is constrained by inverting only the preferred seismic planes. If all the data are kinematically compatible with each other after the inversion procedure, both the necessary and sufficient
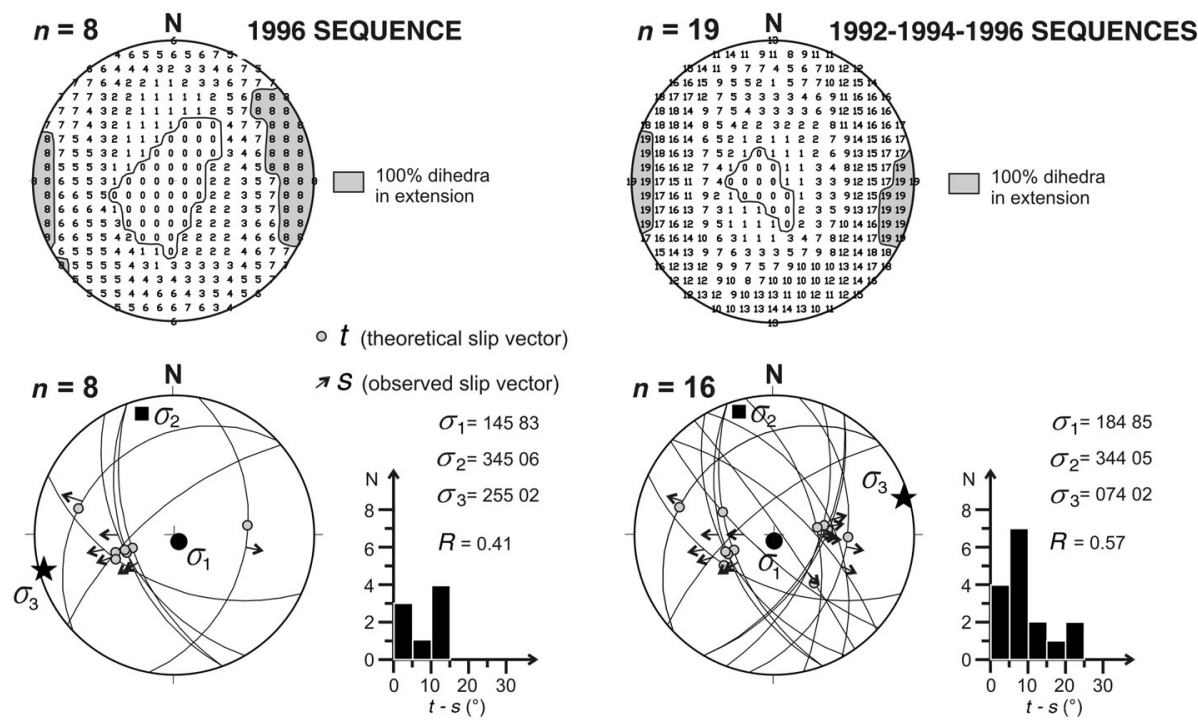

Fig. 5. Stress analysis of the focal mechanisms of 1996 (left) and combined 1992, 1994, 1996 (right) sequences. Top: superposition of extensional dihedra (containing $T$-axes); small numbers indicate the number of dihedra common to each point of the grid (Schmidt projection). Bottom: preferred seismic planes (Wulff projection), observed and theoretical slip vectors, parameters of the stress ellipsoid obtained by inversion and histogram of the angular divergence between theoretical $(t)$ and observed $(s)$ slip vectors. Stress axes are indicated as trend (first three numbers) and plunge (last two numbers); $R$ (shape factor) gives the value of the stress ratio $\left(\sigma_{2}-\sigma_{1}\right) /\left(\sigma_{3}-\sigma_{1}\right)$. 
conditions for computing a common stress tensor are satisfied.

In the case of the 1996 sequence, all the mechanisms are kinematically compatible with a common tensional stress tensor; the representative ellipsoid is triaxial $(R=0.41)$, with a horizontal $\mathrm{N} 255^{\circ}$-trending $\sigma_{3}$ axis (fig. 5).

In order to verify whether the three sequences are compatible with a common tensor representative of the active state of stress in the Northern L'Aquila and Amatrice-Campotosto areas, the 1992, 1994 and 1996 focal mechanisms were inverted all together (19 mechanisms, fig. 5). The application of the right dihera method indicates that the necessary condition for compatibility with a common stress tensor is satisfied. Nevertheless, the inversion procedure indicates that three aftershocks of the 1994 sequence, having NW-SE-trending $T$-axes, are not compatible with the remaining dataset (16 events). The remaining 16 focal mechanisms are compatible with a common tensional tensor; the representative stress ellipsoid is triaxial $(R=$ $=0.57$ ), with a horizontal $\mathrm{N} 74^{\circ}$-trending $\sigma_{3}$ axis.

The kinematic complexity due to the presence of three not compatible 1994 focal mechanisms may be interpreted as due to local disturbances of the regional stress field, which is typically observed in minor seismic sequences (Mercier and Carey-Gailhardis, 1989; Brozzetti and Lavecchia, 1994; Boncio et al., 1996).

\subsection{Thickness of the seismogenic layer}

The frequency distribution of the 1992, 1994 and 1996 hypocentres shows a sharp decrease at depths between 15 and $16 \mathrm{~km}$ (fig. 6). A comparable decrease at depth in the frequency distribution of hypocentres is shown by a quality selection of the Amatrice-Campotosto seismicity reported in the 1981-1996 CST catalogue (ING-GNDT, 2001; A and B quality, depth errors $<4 \mathrm{~km}$; figs. 4 and 6). The accuracy of the 1981-1996 CST hypocentral determinations is relatively low and only a qualitative comparison is admissible. Nevertheless, the observed sharp decrease at depth of the seismicity suggests that the seismogenic layer is about 15$16 \mathrm{~km}$ thick.

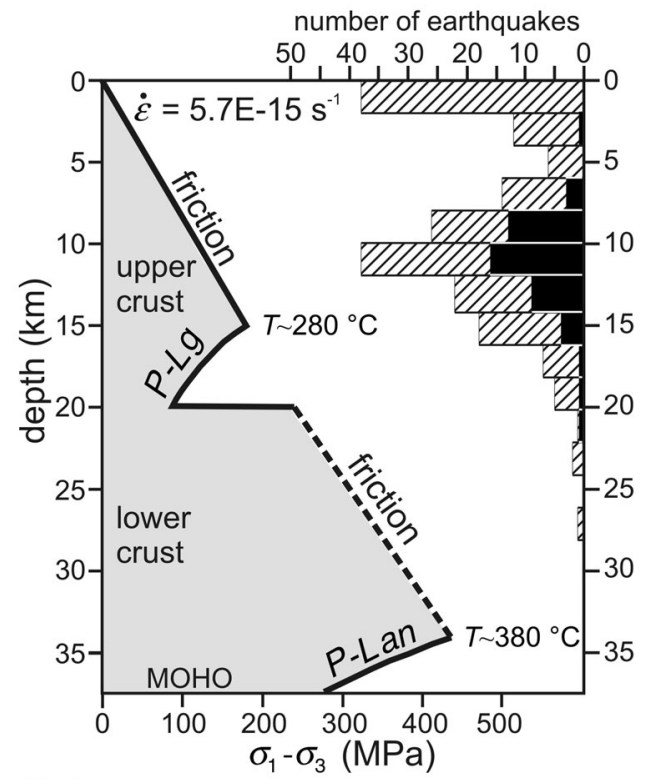

EIT 1981-1996 CST catalogue

1992, 1994 and 1996 sequences

Fig. 6. Rheological profile (in stress difference) for the crust in the Amatrice-Campotosto area and depth distribution of the seismicity (seismicity selection in fig. 4). Frictional failure law for brittle behaviour (friction) and power-law creep rheology for plastic behaviour $(P-L g=$ granite power-law creep; $P$-Lan $=$ $=$ anorthosite power-law creep) are compared; $\dot{\varepsilon}=$ longitudinal strain rate from geodetic measurements (D'Agostino et al., 2001). Creep parameters for granite: $A$ (empirical material constant) $=1.8 E-9 \mathrm{MPa}^{-n} \cdot \mathrm{s}^{-1}$, $n$ (stress exponent) $=3.2, E$ (activation energy) $=$ $=123 \mathrm{~kJ} \cdot \mathrm{mol}^{-1}$; creep parameters for anorthosite: $A=$ $=3.2 E-4 \mathrm{MPa}^{-n} \cdot \mathrm{s}^{-1}, n=3.2, E=238 \mathrm{~kJ} \cdot \mathrm{mol}^{-1}$ (from Ranalli, 1995).

Figure 6 compares the frequency distribution of hypocentres with the first-order strength and behaviour of the crust deduced by rheological profiling (e.g., Ranalli and Murphy, 1987). The strength envelope was computed by comparing linear frictional failure law for normal faulting, under hydrostatic pore-fluid conditions (brittle behaviour; Sibson, 1974; Byerlee, 1978), with power-law creep rheology under constant longitudinal strain rate (Kirby, 1983). The temperatures was calculated starting from 
the regional surface heat flow $\left(40 \mathrm{~mW} / \mathrm{m}^{2}\right.$; Pasquale et al., 1997), under the assumption of steady-state thermal regime (Dragoni et al., 1996). The upper crust underlying the sedimentary cover (from $\sim 8 \mathrm{~km}$ to $\sim 20 \mathrm{~km}$, see fig. $2 \mathrm{~b}$ ) is likely to be of felsic composition, as suggested by the related $P$-wave velocities (see Ponziani et al. (1995) for the detailed stratification of the crust; and Rudnick and Fountain (1995) for the composition inferable from $P$ wave velocities) and was modelled using a granite rheology. The lower crust (depth $>20$ $\mathrm{km}$ ) is likely to be of intermediate composition between felsic and mafic rocks and was modelled using the anorthosite rheology.

A transition from brittle behaviour to bulk plastic flow at depths of $\sim 15 \mathrm{~km}$ was found using a longitudinal strain rate $\dot{\varepsilon}=5.7 \cdot 10^{-15} \mathrm{~s}^{-1}$, obtained in this area by GPS measurements (D'Agostino et al., 2001). The calculated temperatures at the transition is $\sim 280^{\circ} \mathrm{C}$. The brittle/plastic transition in the upper crust predicted by rheological profiling agrees surprisingly well with the sharp decrease in the frequency of earthquakes at depth. The observed consistency between seismological and rheological data suggests that the active structures responsible for the seismicity are mainly bounded within the brittle upper crust and detach at depth onto a horizon dominated by nearly horizontal bulk plastic flow accommodating longitudinal stretching.

\section{The Mt. Gorzano Fault}

\subsection{Structural and morphotectonic features}

The Mt. Gorzano Fault is a well exposed WSW-dipping normal fault which dislocates an Early Pliocene anticline structure (fig. 7) composed, at surface, by Middle-Late Miocene marls (Cerrogna Marls and Pteropodi Marls formations) overlaid by early Messinian siliciclastic turbidites (Laga formation) (Centamore et al., 1991; Marsili and Tozzi, 1991; Calamita et al., 1995; Ghisetti and Vezzani, 2000). In the field, it is possible to map the Mt. Gorzano structure as a continuous fault surface extending for $\sim 28 \mathrm{~km}$. At the northern termination, the fault progressively disappears from both field and aerial photograph observations. In the southern part, the fault may be clearly followed up to the intersection with an E-W-striking Sdipping normal fault belonging to the Gran Sasso normal fault system.

The fault plane is particularly well exposed in the central portion of the structure, where it cuts the Cerrogna Marls formation; it strikes $\mathrm{N} 140-150^{\circ}$ and dips $60-70^{\circ}$ to the SW. The kinematic indicators mainly consist of calcite shear fibres, abrasion striae, grooves and foliated cataclasite. The average slip vector is N220$230^{\circ}$. Fault planes and slickensides are rarely observed in both the northern and southern portions of the fault, where it cuts the low-competent siliciclastic deposits of the Laga formation. Nevertheless, the fault scarp is evident thanks to the presence in the footwall block of massiveto-thick layered arenaceous beds of the basal Laga formation displaced against less competent alternations of pelites and arenites of the upper Laga formation. The few fault planes measured along the northern portion of the fault (north of Amatrice) strike N155-165 ${ }^{\circ}$ and dip steeply $\left(80-85^{\circ}\right)$ to the SW.

In the hanging wall block of the Mt. Gorzano Fault, there are two small basins related to the fault activity and filled by continental deposits: the Amatrice Basin, located in the northern portion, and the Campotosto Basin, located in the central-southern portion (Demangeot, 1965; Blumetti et al., 1993; Cacciuni et al., 1995). In the Amatrice Basin, the outcropping stratigraphic succession consists of Early Pleistocene glacis deposits, overlaid by large landslide bodies, and by terraced fluvial deposits presumably of Middle and Late Pleistocene age (Blumetti et al., 1993). In the Campotosto Basin, the oldest continental deposits are not exposed; the outcropping stratigraphic succession consists of coalescent alluvial fans and heteropic swamp deposits radiocarbon dated to $39700 \pm 3000$ years BP (Bachetti et al., 1990). Geomorphic evidence of the Quaternary fault activity, such as triangular facets and well-preserved fault scarps younger than Early Pleistocene are documented along the slope generated by the Mt. Gorzano Fault (on both Miocene bedrock and Quaternary continental deposits; Blumetti et al., 1993). Clear evidence of displacements on Late Quaternary (Late 


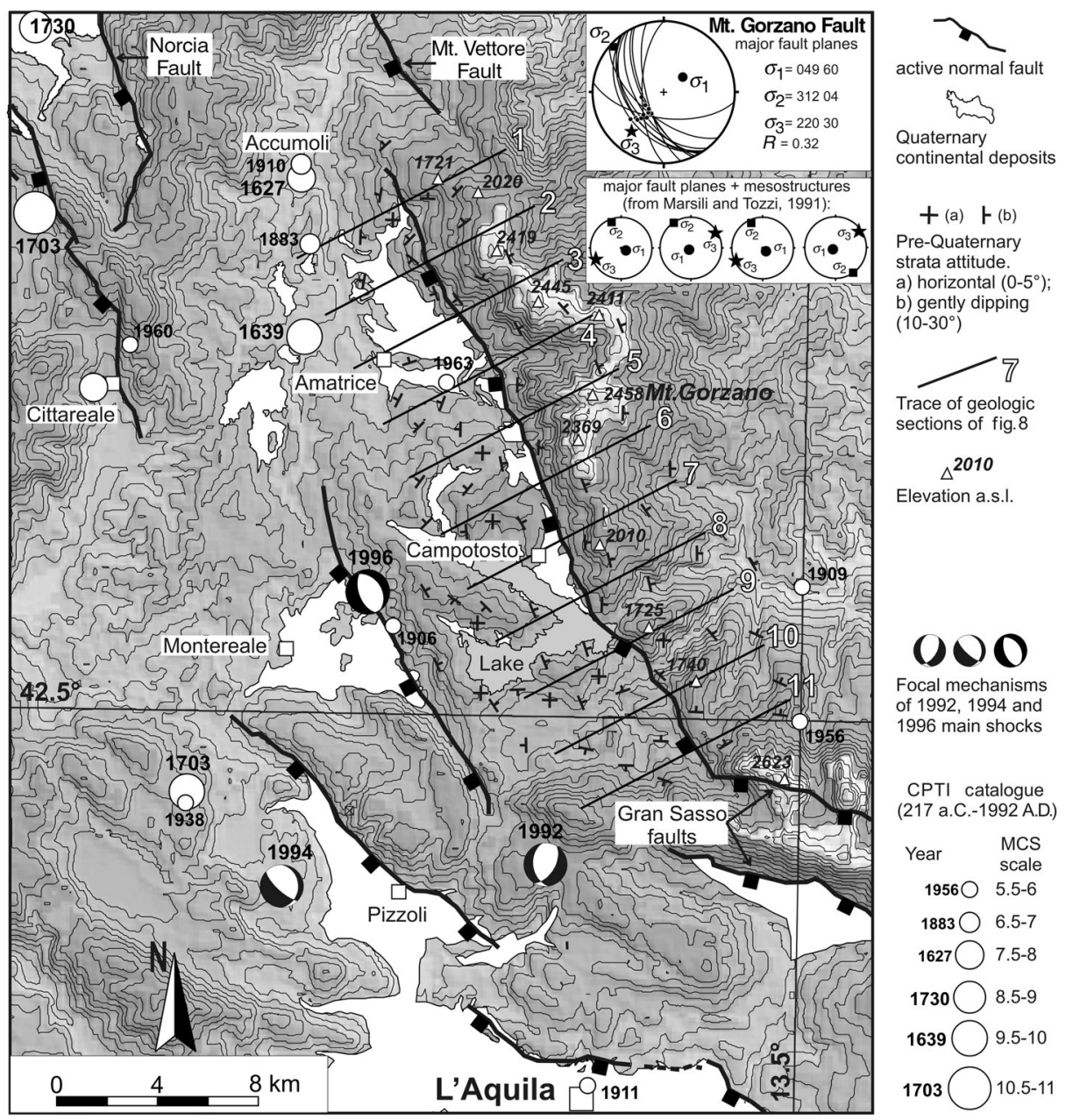

Fig. 7. Structural sketch and topography (contour interval is $100 \mathrm{~m}$ ) of the Amatrice-Campotosto area. Inset at the top right corner: geometry and kinematics of the Mt. Gorzano active normal fault and stress parameters obtained in this work by inversion of major fault planes; the stress axes obtained by inversion of both major and mesostructures (from Marsili and Tozzi, 1991) are also shown.

Pleistocene-Holocene) deposits and morphologies are available only for a fault strand of length of $\sim 20 \mathrm{~km}$, in the central-southern portion of the structure (Galadini and Galli, 2000; Galadini and Messina, 2001). Displacement and tilting of the Late Quaternary Campotosto stratigraphic succession were interpreted by Bachetti et al. (1990) as the expression of repeated coseismic surface faulting. Displacement of Holocene terraced de- posits radiocarbon dated to $6550-6380$ year B.C. is documented by trench excavation across the southern portion of the main fault, near the Campotosto Lake (Galadini and Galli, 2000; Galadini and Messina, 2001).

The presence of two distinct basins in the hanging wall, coupled with the observation that the Late Quaternary activity is evident only in the central-southern portion of the structure, al- 
lowed some authors to hypothesize the presence of two segments of different age: a northern segment of pre-Late Quaternary activity, associated with the Amatrice Basin, and a southern segment of Late Quaternary activity associated with the Campotosto Basin (Galadini and Messina, 2001). Nevertheless, there are no significant geometrical-structural complexities of the fault plane that justify a segmentation. Moreover, the analysis of the fault displacement (see section below) does not support the hypothesis of fault segmentation.

\subsection{Fault displacement and throw rates}

By integrating original field data with geological maps available in the literature (e.g., Centamore et al., 1991; Cacciuni et al., 1995; Vezzani and Ghisetti, 1998), we measured the total fault displacement along 11 cross sections, orthogonal to the fault strike, by correlating ho- mologous stratigraphic markers at the hanging wall and footwall blocks and assuming constant thickness of the lithological units separated by the stratigraphic markers (fig. 8). The stratigraphic markers used are the top of the Cerrogna and Pteropodi Marls formations and the stratigraphic contacts among the different lithological associations of the Laga formation (arenaceous, arenaceous-pelitic and pelitic-arenaceous associations, Centamore et al., 1991). The highest displacement (up to $2300 \mathrm{~m}$ ) was measured along cross section 4; a progressive northward and southward decrease of fault displacement was observed. The along-strike variation of finite displacement helps to constrain the geometry of the Mt. Gorzano structure as an isolated fault, without significant internal segmentation. In our opinion, the separation between the Amatrice and Campotosto basins is mainly related to the presence of a pre-existing structural high, inherited by the contractional tectonics (i.e. the axial culmination of the Mt. Gorzano
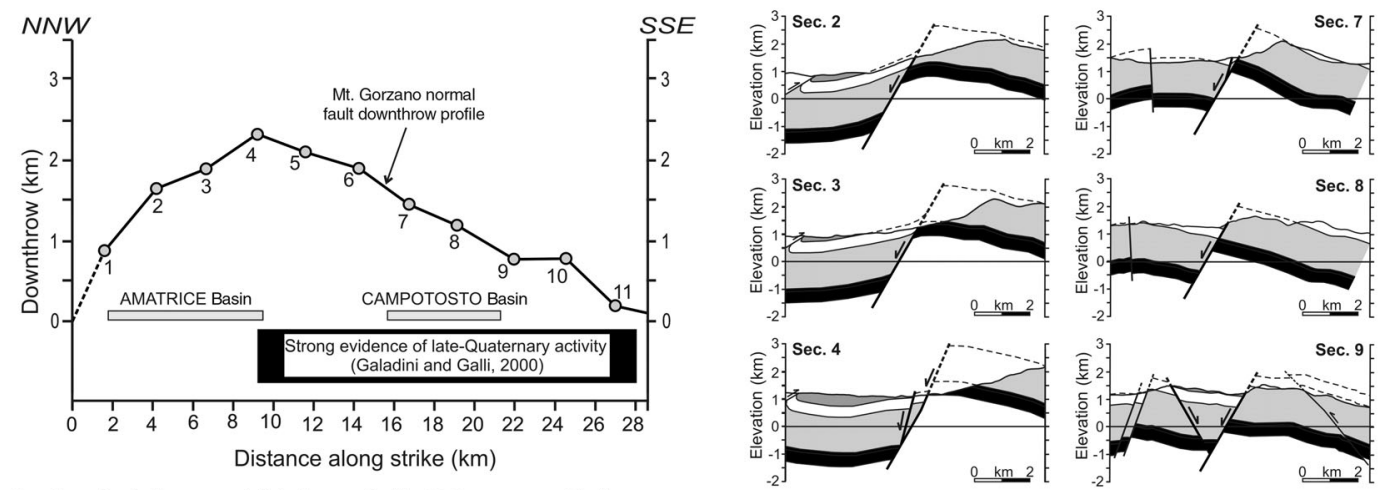

Downthrow (vertical component of displacement) of the Mt. Gorzano normal fault
measured on geologic section
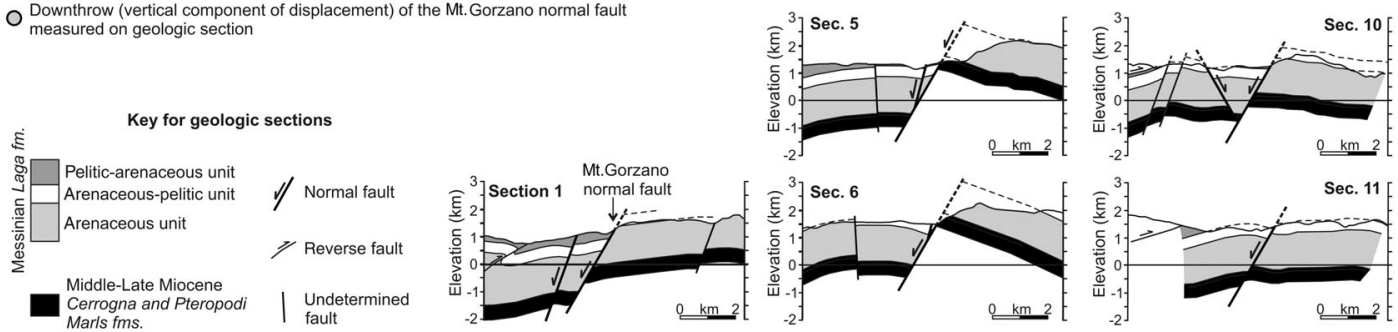

Fig. 8. Geologic sections across the Mt. Gorzano normal fault (location in fig. 7) and diagram illustrating the along-strike variation of the vertical component of net geological displacement. 
anticline; see the geological map by Vezzani and Ghisetti, 1998), rather than to structural complexities associated with normal faulting.

The normal fault post-dated the contractional deformation (Early Pliocene) since at least the Early Pleistocene, which is the age of the oldest syntectonic deposits accumulated in the Amatrice continental basin according to Blumetti et al. (1993). By assuming the onset of the Mt. Gorzano Fault activity at the base of Early Pleistocene (last $1.8 \mathrm{Myr}$ ), we obtain an average throw rate of $\sim 1.3 \mathrm{~mm} / \mathrm{yr}$ along the cross section showing the maximum downthrow (section 4, $2300 \mathrm{~m}$; fig. 8).

Blumetti et al. (1993) reported that both the pebbles and the matrix of the Early Pleistocene glacis deposits of the Amatrice Basin derive almost exclusively from erosion of the Laga formation; the absence of clastic elements from the Cerrogna Marls formation suggests that the Cerrogna Marls were not exposed during the sedimentation of the glacis deposits. In other words, the exposure at surface of the Cerrogna Marls formation at the footwall of the normal fault occurred only after the Early Pleistocene. Along cross section 4, the top of the Cerrogna Marls formation at the footwall of the normal fault is uplifted of $\sim 550 \mathrm{~m}$ compared to the top of the Early Pleistocene glacis deposits at the hanging wall. By averaging the uplift since the Middle Pleistocene (last $0.8 \mathrm{Myr}$ ), we obtain a minimum throw rate of $\sim 0.7 \mathrm{~mm} / \mathrm{yr}$.

Morphotectonic and paleoseismologic analyses by Galadini and Galli (2000) in the centralsouthern portion of the fault, east of Campotosto, indicate a Late Quaternary throw rate, averaged over the last 20-30 kyr, of 0.7-0.9 mm/yr.

\subsection{Paleo-stress tensor}

The fault kinematic data, mainly collected in the central part of the Mt. Gorzano Fault, were inverted to reconstruct the shape and orientation of the paleo-stress tensor (Carey, 1979). The aim was to constrain the stress tensor representative of the mean regional state of stress, possibly unaffected by local stress disturbances. Local stress disturbances often manifest as kinematic complexities on minor faults.
Therefore, we inverted only the striated planes clearly representative of the major fault. This choice has the disadvantage that there is no significant spatial dispersion of the inverted data, giving a numerically less stable solution compared to a randomly distributed data set. For this reason, we also compared our results with those available in the literature and obtained by inversion of both major and minor fault structures (Marsili and Tozzi, 1991).

The inversion procedure indicates that the Mt. Gorzano Fault moved within a mean stress field having a $\mathrm{N} 220^{\circ}$-trending $30^{\circ}$-plunging $\sigma_{3}$ axis, a steeply inclined $\sigma_{1}$ axis and a shape factor $R$ equal to 0.32 (fig. 7). The obtained result is in good agreement with the D2 tensor computed by Marsili and Tozzi (1991), who inverted both major and minor striated faults measured mainly in the footwall block of the Mt. Gorzano Fault. This tensor, considered by Marsili and Tozzi (1991) to be responsible for the formation and motion of the Mt. Gorzano normal fault, is characterised by a nearly horizontal $\sigma_{3}$ axis ranging in trend between $\mathrm{N} 235^{\circ}$ and $\mathrm{N} 245^{\circ}$; the $\sigma_{1}$ axis is nearly vertical (fig. 7).

The Mt. Gorzano paleo-stress tensors are substantially coaxial to the active stress tensor (N74 ${ }^{\circ}$-trending $\sigma_{3}$ axis) computed in this work by inversion of the focal mechanisms (1992, 1994 and 1996 seismic sequences, fig. 5). This suggests that the mean orientation of the deviatoric stress has not basically changed, at regional scale, since Quaternary times. Similar conclusions can be drawn for the whole Central Apennines (Boncio and Lavecchia, 2000).

\section{Discussion and conclusions}

\subsection{Interpreting the long-term geological fea- tures of the Mt. Gorzano normal fault}

The Mt. Gorzano Fault is a Quaternary normal fault $\sim 28 \mathrm{~km}$ long. The along-strike displacement profile is relatively simple, with maximum displacement near the centre progressively tapering off towards the fault tips, as typically observed for isolated faults (e.g., Dawers et al., 1993). The available morphotectonic and paleoseismologic data (Bachetti et al. 1990; 
(a)

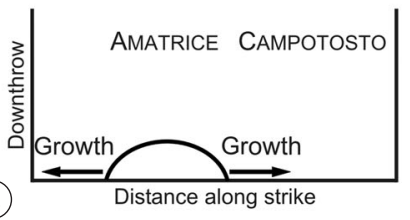

(b)

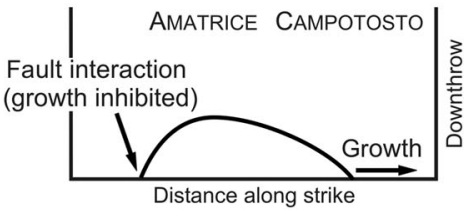

(C)
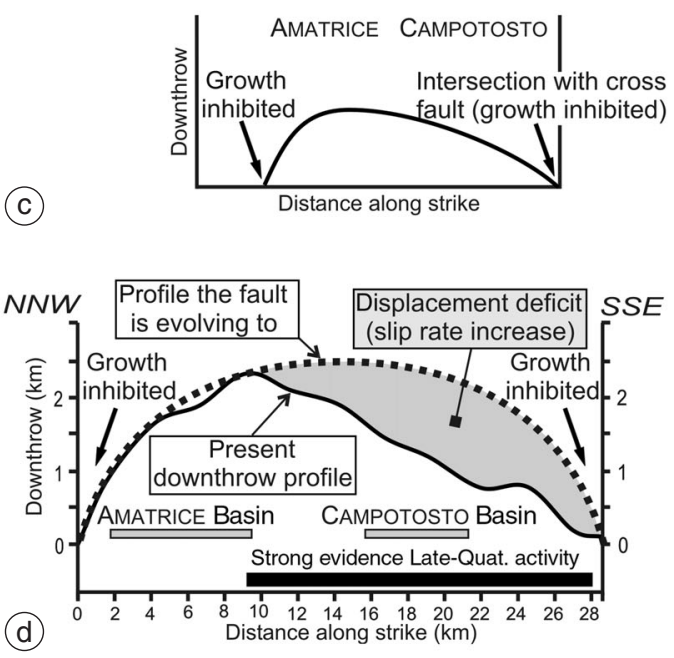

Fig. 9a-d. Schematic evolutionary history of the Mt. Gorzano Fault and related displacement profile: a) fault nucleates and freely grows displacing preexisting contractional structures; b) fault interacts at NNW with the right-stepping Mt. Vettore normal fault; interaction inhibits fault growth towards NNW and displacement gradient increases producing an asymmetric profile; fault freely grows toward SSE; c) fault intersect at SSE the E-W-trending Gran Sasso normal fault; intersection inhibits fault growth towards SSE. d) Present displacement profile and idealized symmetrical profile toward which the fault is evolving to, without further along-strike growth (inhibited by structural complexities): the grey area denotes the displacement deficit the fault has to fill, by relative increase in slip rate, to reach the symmetrical profile; relative increase in slip rate manifests with strong evidence of fault activity during Late Quaternary.
Galadini and Galli, 2000; Galadini and Messina, 2001) clearly indicate that the fault is active, i.e. it has an established record of activity in the Late Quaternary (see Machette, 2000 for a discussion on terminology). An interpretation of the displacement profile in fig. 8 may help to explain why the strongest and clearest evidence of Late Quaternary activity is mainly located in the southern portion of the structure, rather than in the central part (i.e. close to the maximum displacement) as one would expect for an isolated fault. The displacement profile is asymmetric, with a steeper gradient in the northern portion compared to the southern one. Asymmetric profiles may be interpreted as due to interaction with neighbouring faults, which inhibits fault growth along-strike and increases the displacement gradient (Peacock and Sanderson, 1991). The observed steeper gradient in the NNW portion of the fault might result from interaction between the Mt. Gorzano and Mt. Vettore normal faults, which have a right-stepping en échelon arrangement (fig. 7). Toward SSE the Mt. Gorzano Fault is now bounded by a structural complexity represented by the intersection with the E-W-trending Gran Sasso normal fault. Assuming that the Mt. Gorzano Fault cannot grow further along-strike, being bounded by the two described structural complexities, it is reasonable to hypothesise that the fault is now growing only by displacement accumulation. But, before further increasing the maximum displacement, it is likely that the fault will first tend to establish a stable configuration that is, a symmetric displacement profile (fig. 9a-d). In order to readjust the displacement profile, the fault must fill first the displacement deficit in the southern, low-displacement gradient portion of the structure, probably through relative increase of slip rate in that portion (see Cowie and Roberts, 2001). The relative increase in slip rate might be responsible for the strong evidence of displacement at surface during the most recent fault activity (e.g., Late Quaternary).

A possible evolutionary history of the Mt. Gorzano normal fault growth is proposed in fig. $9 \mathrm{a}-\mathrm{d}$. In the frame of this evolutionary model, the throw rates estimated east of Campotosto (0.7-0.9 mm/yr for the last 20-30 kyr, Galadini and Galli, 2000) are probably near the maxi- 
mum values we expect along the fault and are the most appropriate values to be used in fault modelling for seismic hazard purposes.

\subsection{The Mt. Gorzano Fault and the minor seismicity}

During the last twenty years, only small earthquakes $(M \leq 4.0)$ and spread microseismicity have occurred within the hanging wall of the Mt. Gorzano Fault (fig. 4). Minor earthquakes are often of difficult tectonic interpretation, but in the case of the 1992, 1994 and 1996 earthquakes a sufficient amount of data is available, which allows us to hypothesise a genetic link with the Mt. Gorzano Fault activity: i) the three analysed small sequences define, in cross section, a WSW-dipping seismic band located along the down-dip prolongation of the WSW-dipping Mt. Gorzano Fault; ii) the Mt. Gorzano Fault is an active tectonic structure, as testified by the available geologic and paleoseismologic data; iii) the mean state of stress responsible for the minor seismicity (WSW-ENE-trending deviatoric tension) and for the finite Quaternary dis- placement is essentially the same, showing that in the study area the stress field has not changed since the onset of extensional tectonics.

It is certainly difficult to assess if the 1992, 1994 and 1996 earthquakes ruptured small portions (dimensions of the order of $1 \mathrm{~km}^{2}$ ) of the main fault plane or subsidiary structures within the fault zone ( $C$-shears parallel to the main fault, conjugate $R$-shears), or minor structures accommodating volumetric deformation (synthetic and antithetic hanging wall structures, minor structures at fault terminations). The hypocentral determinations have a detail of the order of 0.5-1 $\mathrm{km}$, which is not sufficient for straightforward analysis of such a detail. Nonetheless, some considerations can be made if we compare the distribution of the 1992, 1994 and 1996 seismicity with the 3D geometry of the Mt. Gorzano Fault (fig. 10a,b).

The 1996 sequence is likely to be associated with dislocation on the main fault plane, being well clustered at depth and having a preferred seismic plane which fits well with the prolongation at depth of the Mt. Gorzano Fault. Analogous tectonic meaning may be attributed

Mt. Vettore normal fault
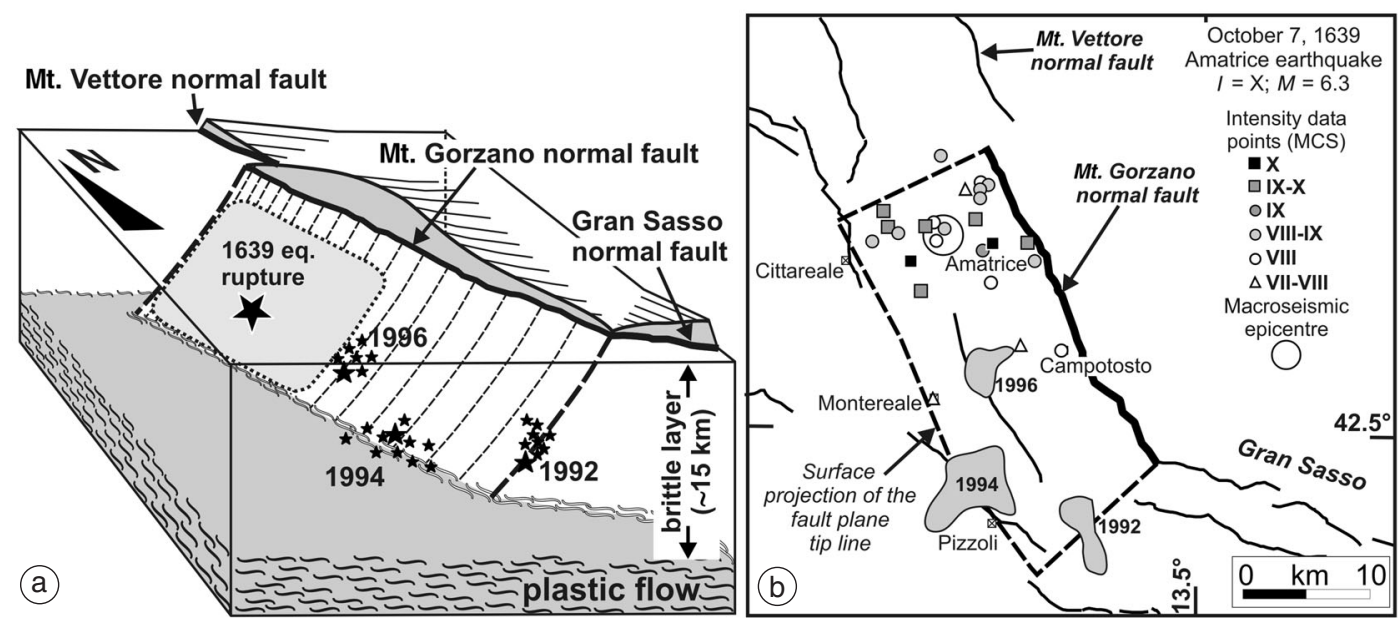

Fig. 10a,b. a) Interpretative block-diagram illustrating the relations between the Mt. Gorzano normal fault and the occurrence of the October 1639 earthquake ( $I=X, M=6.3$; Gruppo di Lavoro CPTI, 1999) and the 1992, 1994 and 1996 seismic sequences; b) projection at surface of the tip line of the Mt. Gorzano normal fault, MCS intensity data points of the 1639 earthquake (I $\geq$ VII-VIII from DOM 4.1 database; Monachesi and Stucchi, 1997) and areas of occurrence of the 1992, 1994 and 1996 sequences. 
to the other minor seismicity recurring in the same area, such as the 5th February, 1906 earthquake ( $I=\mathrm{VI}, M=4.3$ ) (figs. 4 and 7). This minor seismicity might represent recovering of slip of an unbroken (or partially broken) portion of the fault after the last large earthquake on the Mt. Gorzano Fault plane.

The 1992 sequence concentrates at the southern end of the Mt. Gorzano Fault, close to the intersection with the $S$-dipping Gran Sasso normal fault. This sequence, as well as other minor earthquakes occurring in the same area, may be interpreted as seismic dislocations on minor structures accommodating volumetric deformation at the lateral tip of the Mt. Gorzano Fault plane.

The earthquakes of the 1994 sequence are the deepest and most scattered events among the analysed sequences. They may represent deformation at (or in a rock volume around) the deepest tip of the fault, i.e. at the intersection between the fault plane and the base of the brittle layer. Similar tectonic meaning could be attributed to the frequent minor seismicity occurring along the Cittareale-Montereale-Pizzoli alignment (fig. 4). This belt of seismicity, striking nearly parallel to the Mt. Gorzano Fault, might represent the projection at surface of the lower tip of the seismogenic fault plane.

\subsection{The Mt. Gorzano Fault and the major earthquakes}

The largest known earthquake of the area is the 1639 Amatrice earthquake. The shock produced damage up to $\mathrm{X}$ on the MCS scale around Amatrice; damages estimated of VIII MCS were documented within an area extending $12 \times 15 \mathrm{~km}$ within the northern portion of the Mt. Gorzano hanging wall block (DOM 4.1 database, Monachesi and Stucchi, 1997) (fig. 10b). In the CFTI catalogue (Boschi et al., 1997 and references therein), the earthquake is described as a sequence characterised by two clearly separated main shocks ( 8 and 15 of October) preceded by foreshocks and followed by several aftershocks. Within the uncertainties characterising historical records, the described sequence does not look significantly different from well-documented shallow-depth normal faulting sequences occurring in Central Apennines. Examples are the succeeding $M_{w} 5.9$ and $M_{w} 5.5$ shocks of the May 1984 Southern Abruzzo sequence (Del Pezzo et al., 1985; Pace et al., 2002) and the succeeding $M_{w} 5.6$ and $M_{w}$ 6.0 shocks of the September 1997 UmbriaMarche sequence (Amato et al., 1998). In our opinion, the distribution of the 1639 earthquake intensity data points indicate an activation of the northern portion of the Mt. Gorzano Fault; in fact, all the $I \geq$ VIII MCS points lie within the Mt. Gorzano hanging wall block, as reasonably expected for a normal faulting earthquake.

\subsection{Maximum seismogenic potential of the Mt. Gorzano Fault}

A listric geometry at depth of the Mt. Gorzano Fault is hypothesized in this work by considering the surface attitude of the fault, the hypocentral distribution of the 1992, 1994 and 1996 seismic sequences and the attitude of the preferred seismic plane of the 1996 Campotosto sequence (e.g., fig. 4). Therefore, a down-dip width of $\sim 19 \mathrm{~km}$ may be calculated by considering a thickness of the seismogenic layer of $\sim 15 \mathrm{~km}$, as indicated by hypocentral distribution of seismicity and rheological profiling. Considering that the along-strike length at surface is $\sim 28 \mathrm{~km}$, a total fault surface of $\sim 530$ $\mathrm{km}^{2}$ can be calculated.

The average estimated magnitude for the 1639 Amatrice earthquake is 6.3 (Gruppo di Lavoro CPTI, 1999). Applying commonly used scaling-laws, a rupture area of the order of 200 $\mathrm{km}^{2}$ may be estimated (e.g., Wells and Coppersmith, 1994; Hanks and Kanamori, 1979). Assuming a nearly equidimensional rupture (typical of earthquakes smaller than the seismogenic layer, see Scholz, 1990), a width of 14-15 km may be calculated for the rupture area. Then, the 1639 event did not rupture the whole Mt. Gorzano Fault surface, but only its northern half (fig. 10a).

A stimulating question, having implications on seismic hazard, arises at this point: may a future earthquake rupture the entire, $28 \mathrm{~km}$ long, Mt. Gorzano Fault surface? Or must the fault be 
considered split into two seismogenic sources, one corresponding to the 1639 rupture and the other one silent since historical times (Valensise and Pantosti, 2001)? Or must only the centralsouthern portion of the fault, $\sim 20 \mathrm{~km}$ long, showing clear evidence of Late Quaternary activity and silent since historical times, be considered the seismogenic source, with maximum attended magnitude of $\sim 6.6$ (Barchi et al. 2000; Galadini and Galli, 2000)?

In our opinion, agreed that the 1639 earthquake can be associated with the northern portion of the Mt. Gorzano Fault, the occurrence of a larger event activating at depth the whole 28 $\mathrm{km}$ long fault plane should be considered on the basis of the following points:

a) The structural data presented and discussed in this paper show that the Mt. Gorzano Fault is not split into two segments, but is a continuous segment, not interrupted by significant geometrical or structural complexity. Significant variations in behavioural properties of the fault at depth are unlikely, considering that there are no lateral variations in the displaced stratigraphic succession. In any case, behavioural variations are difficult to assess.

b) The occurrence of a large earthquake with expected magnitude of $\sim 6.6$ is proposed by Galadini and Galli (2000) by considering the length of the fault strand showing clear Late Quaternary activity $(20 \mathrm{~km})$ as the expression of the Surface Rupture Length (SRL) of the maximum expected earthquake, and by applying empirical relations (Wells and Coppersmith, 1994). A SRL of $\sim 20 \mathrm{~km}$ implies a much longer rupture at depth (subsurface rupture length, RLD). Actually, the Wells and Coppersmith (1994) statistical analysis suggests that for normal faulting earthquakes the RLD is longer than SRL up to $\sim 40 \%$. In order to obtain a $M=6.6(\mathrm{SRL}=20 \mathrm{~km})$, the RLD should be in the range of $28-29 \mathrm{~km}$, which is similar to the length of the Mt. Gorzano Fault obtained in this work by structural analysis $(28 \mathrm{~km})$. This suggests that the dimensions of the fault from structural reconstructions and from paleoseismologic-morphotectonic evidence are not conflicting but complementary quantities. A large earthquake may rupture the entire Mt. Gorzano structure $(\sim 28 \mathrm{~km})$ at depth, producing surface faulting along a large portion of the fault (up to $20 \mathrm{~km}$ ). The apparently anomalous location of the SRL in the southern part of the fault, rather than in the centre, might be explained by considering the model of displacement profile readjustment discussed in Section 6.1.

c) The historical seismicity of central Italy suggests that active faults may be activated first by moderate-to-large events on a portion of the fault and later by larger events on almost all the fault extent. An example is the $29 \mathrm{~km}$ long Norcia fault, located few kilometres NW of the Mt. Gorzano Fault (figs. 1 and 7). The Norcia Fault was activated first on its northern portion by the 1328 earthquake $(M=6.4)$. After 375 years, it was activated by the large 1703 event $(M=6.8)$, which probably ruptured the whole fault length from SE to NW (see Galadini et al., 1999; Lavecchia et al., 2002). Therefore, we suggest that the 1639 earthquake occurred on the Mt. Gorzano Fault but it is not the largest expected event, the dimension of which is constrained by the dimension of the total Mt. Gorzano Fault surface $\left(\sim 530 \mathrm{~km}^{2}\right)$.

The maximum seismogenic potential of the Mt. Gorzano Fault may be estimated by using the relation between fault area $(A)$ and seismic moment $\left(M_{0}\right)$, assuming constant strain drop $\left(M_{0}=G D A=G D L W=G k L^{2} W\right.$ where $G=$ shear modulus; $A=W L=$ fault area; $D=$ average coseismic displacement; $k=D / L=$ strain drop). With constant strain drop of $3 * 10^{-5}$ (normal faulting earthquakes in Italy; Selvaggi, 1998), an equivalent seismic moment of $1.34 * 10^{19} \mathrm{Nm}$ is calculated for an earthquake rupturing the entire fault surface of $\sim 530 \mathrm{~km}^{2}$ ( $G$ is assumed to be $\left.3 * 10^{10} \mathrm{~Pa}\right)$. Relating the seismic moment to the magnitude (Hanks and Kanamori, 1979), a maximum magnitude of $\sim 6.7$ may be predicted. The results do not change significantly even if we leave out from the seismic moment calculation the portion of the fault surface lying within the top $2 \mathrm{~km}$ of the crust. This could be considered within the field of the stable frictional sliding (shallower than the upper stability transition; Scholz, 1990).

We are conscious that the above calculation, based on a rectangular-shaped source, is a simplification. In fact, natural earthquakes have inhomogeneous distribution of slip. Moreover, it is 
unlikely that the largest hypothesised earthquake would activate $100 \%$ of the «available» fault plane. It is also reasonable that our rectangularshaped fault model underestimates the real fault area (elliptical-shaped surface, see Walsh and Watterson, 1988). Thus, we believe that the adopted assumptions are a reasonable compromise between observable features (surface data) and deep features (fault shape at depth and inhomogeneity of the rupture process). Synthesising, a magnitude ranging from 6.6 (from empirical relations on SRL) to 6.7 (analytically determined from equivalent $M_{0}$ ) sounds like a reasonable estimate for the maximum seismogenic potential of the Mt. Gorzano Fault, in agreement with both structural and morphotectonic-paleoseismologic observations. Such a magnitude value is not new for earthquake normal faulting in central Italy, as testified by the historical seismicity (Gruppo di Lavoro CPTI, 1999).

\section{Acknowledgements}

The authors are grateful to S. Barba and R. Basili for improving the manuscript with their critical reviews and suggestions. This study was supported by MURST grants to G. Lavecchia.

\section{REFERENCES}

Amato, A., R. Azzara, C. Chiarabba, G.B. Cimini, M. Cocco, M. Di Bona, L. Margheriti, S. Mazza, F Mele, G. Selvaggi, A. Basili, E. Boschi, F. Courboulex, A. Deschamps, S. Gaffet, G. Bittarelli, L. Chiaraluce, D. Piccinini and M. RiPePe (1998): The 1997 Umbria-Marche, Italy, earthquake sequence; a first look at the main shocks and aftershocks, Geophys. Res. Lett., 25, 2861-2864.

ANGelier, J. and P. MECHLER (1977): Sur une méthode graphique de recherche des contraintes principales également utilisable en tectonique et en sismologie: la methode des diedres droits, Bull. Soc. Geol. France, 6, 1309-1318.

Bachetti, C., A.M. Blumetti, G. CAlderoni and M. RiDOLFI (1990): Attività neotettonica e paleosismica nel settore meridionale dei Monti della Laga, Rend. Soc. Geol. Ital., 13, 9-16.

Bagnaia, R., A.M. Blumetti, G. De Luca, A. Gorini, S. Marcucci, P. Marsan, G. Milana, R. Salvucci and E. ZAmBonelli (1996): Morfotettonica dei rilievi a nord della conca aquilana, Il Quaternario, 9, 287-292.

Barchi, M., F. Galadini, G. Lavecchia, P. Messina, A.M.
Michetti, L. Peruzza, A. Pizzi, E. Tondi and E. VitTORI (Editors) (2000): Sintesi delle Conoscenze sulle Faglie Attive in Italia Centrale: Parametrizzazione ai Fini della Carattrizzazione della Pericolosità Sismica (CNR-GNDT, Roma), pp. 62.

Bigi, G., D. Cosentino, M. Parotto, R. Sartori and P. SCANDONE (1992): Structural Model of Italy and gravity map, Quad. Ric. Sci. (CNR), 114/3, 1990.

BlumetTI, A.M. (1995): Neotectonic investigations and evidence of paleoseismicity in the epicentral area of the January-February 1703, Central Italy, earthquakes, in Perspectives in Paleoseismology, edited by L. SERVA, vol. 6, 83-100.

Blumetti, A.M., F. Dramis and A.M. Michetti (1993): Fault-generated mountain fronts in the central Apennines (Central Italy): geomorphological features and seismotectonic implications, Earth Surf. Proc. Land., 18, 203-223.

Boncio, P. and G. LAVECCHIA (2000): A structural model for active extension in Central Italy, J. Geodynamics, 29, 233-244.

Boncio, P., F. BROzZETTI and G. LAVECCHIA (1996): State of stress in the Northern Umbria-Marche Apennines (Central Italy): inferences from microearthquake and fault kinematic analyses, Ann. Tectonicae, 10, 80-97.

Boschi, E., E. Guidoboni, G. Ferrari, G. VAlensise and P. GASPERINI (Editors) (1997): Catalogo dei Forti Terremoti in Italia dal 461 a.C. al 1990 (ING, Roma-SGA, Bologna), vol. 2, pp. 644.

BROZZETTI, F. and G. LAVECCHIA (1994): Seismicity and related extensional stress field: the case of the Norcia seismic zone (Central Italy), Ann. Tectonicae, 8, 36-57.

Byerlee, J.D. (1978): Friction of rocks, Pure Appl. Geophys., 116, 615-626.

Cacciuni, A., E. Centamore, R. Di Stefano and F. Dramis (1995): Evoluzione morfotettonica della conca di Amatrice, Studi Geologici Camerti, 1995/2, 95-100.

Calamita, F. and A. PizZi (1992): Tettonica quaternaria nella dorsale appenninica umbro-marchigiana e bacini intrappenninici associati, Studi Geologici Camerti, 1995/1, 171-182.

Calamita, F., E. Centamore, G. Deiana and M. Ridolfi (1995): Caratterizzazione geologico-strutturale dell'area marchigiano-abruzzese esterna (Appennino centrale), Studi Geologici Camerti, 1992/1, 17-25.

CAREY, E. (1979): Recherche des directions principales de contraintes associées au jeu d'une population de failles, Rev. Geol. Dyn. Geogr. Phys., 21, 57-66.

Cello, G., S. Mazzoli, E. Tondi and E. Turco (1997): Active tectonics in the central Apennines and possible implications for seismic hazard analysis in peninsular Italy, Tectonophysics, 272, 43-68.

Centamore, E., G. Cantalamessa, A. Micarelli, M. Potetti, D. Berti, S. Bigi, C. Morelli and M. Ridolfi (1991): Stratigrafia e analisi di facies dei depositi del Miocene e del Pliocene inferiore dell'avanfossa marchigiano-abruzzese e delle zone limitrofe, Studi Geologici Camerti, 1991/2, CROP 11, 125-131.

Console, R. and R. Di Giovambattista (1987): Local earthquake relative location by digital records, Phys. Earth Planet. Int., 47, 43-49.

CowIE, P.A. and G.P. RoberTs (2001): Constraining slip rates and spacings for active normal faults, J. Struct. 
Geol., 23, 1901-1915.

D'Agostino, N., R. Giuliani, M. Mattone and L. BonC (2001): Active crustal extension in the Central Apennines (Italy) inferred from GPS measurements in the interval 1994-1999, Geophys. Res. Lett., 28, 2121-2124.

DAwERs, N.H., M.H. ANDERS and C.H. SchOlZ (1993): Growth of normal faults: displacement-length scaling, Geology, 21, 1107-1110.

De Luca, G., R. Scarpa, L. Filippi, A. Gorini, S. MarcuCCi, P. Marsan, G. Milana and E. Zambonelli (2000): A detailed analysis of two seismic sequences in Abruzzo, Central Apennines, Italy, J. Seismol., 4, 1-21.

Del Pezzo, E., G. De Natale, G. Iannaccone, M. MartiNI, R. ScARPa and A. Zollo (1985): Analisi preliminare della sequenza sismica dell'Abruzzo mediante i dati di una rete sismica digitale, in Proceedings $I V$ GNGTS, Roma, 79-96.

Demangeot, J. (1965): Memoires et documents: Géomorphologie des Abruzzes Adriatiques, Cent. Rech. Doc. Cart. Geog., num. H.s. (CNRS, Paris), 115-138.

Dragoni, M., C. Doglioni, F. Mongelli and G. Zito (1996): Evaluation of stress in two geodynamically different areas; stable foreland and extensional backarc, Pure Appl. Geophys., 146, 319-341.

Galadini, F. and P. Galli (2000): Active tectonics in the Central Apennines (Italy): input data for seismic hazard assessment, Nat. Hazards, 22, 225-270.

Galadini, F., P. Galli, I. Leschiutta, G. Monachesi and M. STUCCHI (1999): Active tectonics and seismicity in the area of the 1997 earthquake sequence in Central Italy: a short review, J. Seismol., 3, 165-175.

Galadini, F. and P. Messina (2001): Plio-Quaternary changes of the normal fault architecture in the Central Apennines (Italy), Geodin. Acta, 14, 321-344.

GhisetTi, F. and L. VeZZANi (2000): Detachments and normal faulting in the Marche fold-and-thrust belt (central apennines, Italy): inferences on fluid migration paths, J. Geodyn., 29, 345-369.

GRUPPO DI LAVORO CPTI (1999): Catalogo Parametrico dei Terremoti Italiani (ING, GNDT, SGA, SSN, Bologna), pp. 92.

HANKS, T.C. and H. KANAMORI (1979): A moment-magnitude scale, J. Geophys. Res., 84, 2348-2350.

KIRBY, S.H. (1983): Rheology of the Lithosphere, Rev. Geophys. Space Phys., 21, 1458-1487.

ING-GNDT (2001): Catalogo Strumentale dei Terremoti Italiani dal 1981 al 1996, Version 1.0 (CD-ROM).

LAHR, J.C. (1999): HYPOELLIPSE: a computer program for determining local earthquake hypocentral parameters, magnitude, and first-motion pattern (Y2K Compliant Version), U.S. Geol. Surv. Open-file Rep. 99-023 (paper and on-line editions), pp. 112.

Lavecchia, G., P. Boncio, F. BRozzetti, M. STUCCHI and I. LESCHIUTTA (2002): New criteria for seismotectonic zoning in Central Italy: insights from the UmbriaMarche Apennines, Boll. Soc. Geol. Ital., 1, 881-890.

MachetTe, M.N. (2000): Active, capable, and potentially active faults; a paleoseismic perspective, J. Geodyn., 29, 387-392.

MarsiLi, P. and M. Tozzi (1991): Successione di eventi deformativi nei Monti della Laga: il settore di Monte Gorzano (Rieti), Studi Geologici Camerti, 1991/2, CROP 11, 71-78.
Mercier, J.L. and E. Carey-Gailhardis (1989): Regional state of stress and characteristic fault kinematics instabilities shown by aftershock sequences: the aftershock sequence of the 1978 Thessaloniki (Greece) and 1980 Campania-Lucania (Italy) earthquakes as examples, Earth Plan. Sci. Lett., 92, 247-264.

MONACHESI, G. and M. STUCCHI (Editors) (1997): DOM 4.1: un Database di Osservazioni Macrosismiche di Terremoti di Area Italiana al di Sopra della Soglia del Danno (GNDT, Milano) (available on-line at http://emidius.mi.ingv.it/DOM).

NiCOLICH, R. (1981): Il profilo Latina-Pescara e le registrazioni mediante OBS nel Mar Tirreno, in Proceedings 1st GNGTS, Roma, 621-637.

Pace, B., P. Boncio and G. Lavecchia (2002): The 1984 Abruzzo earthquake (Italy): an example of seismogenic process controlled by interaction between differently-oriented sinkinematic faults, Tectonophysics, 350, 237-254.

Pasquale, V., M. Verdoya, P. Chiozzi and G. Ranalli (1997): Rheology and seismotectonic regime in the Northern Central Mediterranean, Tectonophysics, 270, 239-257.

Peacock, D.C.P. and D.J. SANDERson (1991): Displacements, segment linkage and relay ramps in normal fault zones, J. Struct. Geol., 13, 721-733.

PIZZI, A. and V. SCISCIANI (2000): Methods for determining the Pleistocene-Holocene component of displacement on active faults reactivating pre-Quaternary structures: examples from the Central Apennines (Italy), J. Geodyn., 29, 445-457.

Ponziani, F., R. De Franco, G. Minelli, G. Biella, C. FEDERICO and G. PIALLI (1995): Crustal shortening and duplication of the Moho in the Northern Apennines: a view from seismic refraction data, Tectonophysics, 252, 391-418.

RANALLI, G. (1995): Rheology of the Earth (Chapman \& Hall, London), 2nd edition, pp. 413.

Ranalli, G. and D.C. MurPhY (1987): Rheological stratification of the lithosphere, Tectonophysics, 132, 281295.

REASENBERG, P.A. and D. OPPENHEIMER (1985): FPFIT, FPPLOT, and FPPAGE: Fortran computer programs for calculating and displaying earthquake fault-plane solutions, U.S. Geol. Surv. Open-File Rep. 85-739.

RuDNICK, R.L. and D.M. FOUNTAIN (1995): Nature and composition of the continental crust: a lower crustal perspective, Rev. Geophys., 33, 267-309.

Scherbaum, F. (1996): Of Poles and Zeros, Fundamentals of Digital Seismology (Kluwer Academic Publishers), pp. 268.

Scherbaum, F. and J. Johnson (1992): PITSA, Programmable Interactive Toolbox for Seismological Analysis, IASPEI Software Library, vol. 5.

Scholz, C.H. (1990): The Mechanics of Earthquakes and Faulting (Cambridge University Press, Cambridge), pp. 439.

SElVAGGI, G. (1998): Spatial distribution of horizontal seismic strain in the Apennines from historical earthquakes, Ann. Geofis., 41 (1), 241-251.

SiBSON, R.H. (1974): Frictional constraints on thrust, wrench and normal faults, Nature, 249, 542-544.

STUCCHI, M. (1985): The earthquakes in central Italy, January-February 1703 . Some questions, some preliminary 
answers, in Atlas of Isoseismal Maps of Italian Earthquakes, edited by D. PostPISchl, Quad. Ric. Sci., 114 (2A), 56-57.

VAlEnsise, G. and D. PANTosti (Editors) (2001): Database of potential sources for earthquakes larger than M 5.5 in Italy, Ann. Geofis., 44 (suppl. to n. 4) pp. 180 (with CD-ROM).

VeZZAni, L. and F. GhisetTi (1998): Carta Geologica dell'Abruzzo (1:100000 scale), (SELCA, Florence).

WALSH, J.J. and J. WATTERSON (1988): Analysis of the rela- tionship between displacements and dimensions of faults, J. Struct. Geol., 10, 239-247.

WelLs, D.L. and K.J. COPPERSMITH (1994): New empirical relationships among magnitude, rupture length, rupture width, rupture area, and surface displacement, Bull. Seismol. Soc. Am., 84, 974-1002.

(received November 3, 2003; accepted August 18, 2004) 